\title{
Keanekaragaman Mangrove dan Pemanfaatannya Di Desa Daiama, Kecamatan Landu Leko, Kabupaten Rote Ndao, Propinsi Nusa Tenggara Timur
}

\section{Mangrove Diversity and Its Use in Daiama Village, Landu Leko District, Rote Ndao Regency, East Nusa Tenggara Province}

\author{
Ratna B. Ngoma, Arnold Ch Hendrik*, Apriliana Ballo \\ Program Studi Pendidikan Biologi, Universitas Kristen Artha Wacana, Kupang. Correspondent email: \\ arnold_hendrik@yahoo.co.id
}

Received: 24 July 2020 | Accepted: 5 November 2020 | Published: 10 November 2020

\begin{abstract}
Abstrak. Mangrove merupakan ekosistem utama pendukung kehidupan yang penting di wilayah pesisir dan lautan. Jenis-jenis mangrove di Desa Daiama khususnya Pulau Rote, pulau paling selatan Indonesia sampai saat ini belum diinventarisasi. Penelitian ini bertujuan untuk mengetahui struktur vegetasi mangrove dan pemanfaatannya di Desa Daiama, Kecamatan Landu Leko, Kabupaten Rote Ndao. Teknik pengumpulan data struktur vegetasi mangrove dilakukan dengan membuat peletakan sebanyak plot 16 pada 4 stasiun. Penempatan plot dilakukan dengan metode purposive sampling. Data pemanfaatan diperoleh dengan wawancara terhadap masyarakat Desa Daiama. Hasil penelitian yang diperoleh terdapat 11 jenis mangrove yang terdapat di Desa Daiama yang terdiri dari 6 family, antara lain: Rhizophoraceae (Rhizophora stylosa, Rhizophora mucronata, Ceriops spp, Ceriops tagal, Ceriops decandra, dan Bruguiera sexangula), Soneratiaceae (Soneratia alba), Lythraceae (Pemphis acidula), Myrsinaceae (Aegiceras floridum), Rubiaceae (S.hydrophylacea), Sapindaceae (Dodonaea viscose). Jenis mangrove yang paling dominan untuk tingkat pohon yaitu Rhizophora stylosa $(89,54 \%)$, pancang yaitu Ceriops tagal (40,02\%), dan tingkat semai Phempis acidula (59,09\%). Indeks keanekaragaman vegetasi mangrove di Desa Daiama tergolong sedang pada setiap stasiun yaitu berkisar 1,67-2,00. Pemanfaatan mangrove di Desa Daiama tercatat dijadikan bahan obat, kayunya bahan bangunan dan pembuatan perahu, buah mangrove dijadikan bahan makanan, digunakan sebagai pewarna alami kain tenun.
\end{abstract}

Kata kunci: Vegetasi mangrove, desa Daiama, keaneragaman, pemanfaatan

Abstract. Mangroves are the main life-supporting ecosystem that is important in coastal areas and oceans. Until now, mangrove species in Daiama Village, especially Rote Island, the southernmost island of Indonesia, have not been inventoried. This study aims to determine the structure of mangrove vegetation and its utilization in Daiama Village, Landu Leko District, Rote Ndao Regency. The technique of collecting data on mangrove vegetation structure was carried out by placing 16 plots at 4 stations. Plot placement was done by using purposive sampling method. Utilization data were obtained by interviewing the people of Daiama Village. The results obtained were 11 types of mangroves in Daiama Village consisting of 6 families, including: Rhizophoraceae (Rhizophora stylosa, Rhizophora mucronata, Ceriops spp, Ceriops tagal, Ceriops decandra, and Bruguiera sexangula), Soneratiaceae (Soneratia alba), Lythraceae (Pemphis acidula), Myrsinaceae (Aegiceras floridum), Rubiaceae (S.hydrophylacea), Sapindaceae (Dodonaea viscose). The most dominant mangrove species for tree level were Rhizophora stylosa (89.54\%), saplings, namely Ceriops tagal (40.02\%), and Phempis acidula seedling level (59.09\%). The mangrove vegetation diversity index in Daiama Village is classified as moderate at each station, which ranges from 1.67 to 2.00. The use of mangroves in Daiama Village is recorded as medicinal, for building wood and for making boats, mangroves for food, used as natural dye for woven fabrics.

Keywords: Vegetation mangrove, Daiama village, diversity, utility.

\section{PENDAHULUAN}

Hutan mangrove secara alami dipengaruhi oleh pasang surut air laut, tergenang pada saat pasang naik dan bebas dari genangan pada saat pasang rendah (Kusmana et al., 2002). Mangrove merupakan daerah peralihan (ekoton) yang unik karena menghubungkan daratan dan lautan 
dengan fungsi yang sangat khas dan tidak tergantikan (Ramses, 2016). Mangrove merupakan ekosistem utama pendukung kehidupan yang penting di wilayah pesisir dan lautan yang berperan sebagai penahan abrasi, amukan angin taufan dan tsunami, penyerap limbah, pencegah intrusi air laut. Selain itu mangrove mempunyai fungsi ekologis sebagai penyedia nutrien bagi biota perairan, tempat pemijahan dan asuhan bagi berbagai macam biota. Mangrove diketahui merupakan tempat hidup atau menempel bagi beberapa Mollusca seperti Littoraria sp, Nerita planospira, Nerita Balteata, Cerhitium rostratum, dan beberapa mollusca lain (Ramses et al., 2014). Mangrove juga mempunyai fungsi ekonomis seperti penyedia kayu, daun-daunan, dan bahan baku obat-obatan (Dahuri et al., 1996).

Nusa Tenggara Timur adalah provinsi kepulauan yang memiliki garis pantai sepanjang $\pm 5.700 \mathrm{~km}$ yang sebagian besar ditumbuhi oleh vegetasi mangrove. Timuli (2015) telah melakukan inventarisasi keanekaragaman mangrove di Pantai Kaisulun, Desa Akle, Kecamatan Semau, Kabupaten Kupang, dan telah melaporkan beberapa jenis mangrove yaitu : api-api (Avicenia marina), pedada (Sonneratia alba), bakau (Rhizophora apiculata), bakau hitam (Rhizophora mucronata), tengar (Ceriops tagal), dan bakau (Rhizophora stylosa). Namun demikian, pada kawasan di pulau paling selatan seperti di Desa Daiama Pulau Rote, belum ada laporan tentang keanekaragaman mangrove di daerah ini.

Desa Daiama, Kecamatan Landu Leko, Kabupaten Rote Ndao memiliki ekosistem hutan mangrove yang relatif masih alami. Karena belum ada vegetasi dari luar sehingga belum ada perhatian dari pihak tertentu. Bagi masyarakat Desa Daiama, keberadaan hutan mangrove yang sangat penting sebagai penopang kehidupannya. Secara langsung dan tidak langsung ini telah dirasakan oleh masyarakat Desa Daiama yang mana kawasan hutan mangrove menjadi tempat untuk mencari ikan, udang, kepiting, dan untuk tempat budidaya perikanan, pembuatan garam, budidaya rumput laut, serta kayunya digunakan untuk pembuatan perahu.

Ekosistem hutan mangrove di Desa Daiama mempunyai potensi yang cukup tinggi dan kaya akan manfaat. Telah diketahui bahwa di beberapa ekosistem mangrove pemanfaatan oleh aktivitas manusia mengakibatkan tekanan yang menyebabkan kerusakan mangrove, bentukbentuk pemanfaatan tersebut seperti pembukaan tambak, pengambilan kayu untuk tujuan komersial, perubahan menjadi lahan pertanian dan reklamasi untuk pembangunan (Muryani et al, 2011; Thomas et al., 2017; Poedjirahajoe dan Matatula, 2019). Mengingat manfaat hutan mangrove secara ekologis maka perlu pengelolaan untuk menjaga keberlanjutannya dari tekanan-tekanan yang menyebabkan kerusakan ekosistem mangrove tersebut. Eksplorasi untuk mengetahui keanekaragaman jenis mangrove, struktur tegakan dan dan kelimpahan populasi mangrove merupakan langkah awal untuk dapat menentukan langkah pengelolaan yang tepat bagi ekosistem mangrove. Data-data jenis mangrove dan penyebarannya dapat membantu pemilihan jenis mangrove untuk ditanam dalam proses restorasi jika terjadi kerusakan, sehingga restorasi lebih tepat dan memperbesar keberhasilan restorasi (Alwidakdo et al., 2014). Data struktur tegakan mencerminkan dinamika populasi dan hubungannya dengan lingkungan, yang memungkinkan untuk kita memahami perkembangan populasi suatu spesies (Kai et al., 2013; Li dan Zhang, 2015). Data struktur tegakan dapat membantu untuk pengambilan keputusan dalam pemanfaatan dan pengelolaan mangrove. 
Selain data-data terkait jenis dan struktur tegakan, data bentuk-bentuk pemanfaatan mangrove oleh masyarakat juga perlu untuk diketahui sehingga pengelolaan dapat mempertimbangkan aspek kebutuhan masyarakat lokal. Dengan nilai ekonomi dari ekosistem mangrove cukup besar, sebagai contoh di Pesisir Kota Singkawang nilai manfaat ekonomi mangrove mencapai Rp. 248.184.754.76/ha/thn (Jumaedi, 2016). Dengan memperhatikan kebutuhan masyarakat dalam memanfaatkan nilai ekonomi mangrove serta melibatkan masyarakat dalam pengelolaan maka pelestarian ekosistem mangrove akan lebih berhasil (Febryano et al., 2014; Utomo et al., 2017). Karena pengelolaan mangrove yang tepat membutuhkan keseimbangan antara nilai-nilai jasa lingkungan dan kebutuhan dan keinginan masyarakat lokal (Davinsy et al., 2015; Dencer-Brown et al., 2018). Karena itu penelitian ini dilakukan untuk mengetahui keanekaragaman dan kelimpahan mangrove dan pemanfaatannya oleh masyarakat.

\section{METODE PENELITIAN}

Waktu penelitian dilaksanakan pada bulan September 2018 dan penelitian dilaksanakan di hutan mangrove Pulau Rote, Desa Daiama, Kecamatan Landu Leko, Kabupaten Rote Ndao, Provinsi Nusa Tenggara Timur. Penelitian ini merupakan penelitian jenis survey yang dilakukan terhadap populasi jenis-jenis mangrove dan survey pemanfaatan mangrove oleh masyarakat Desa Daiama.

\section{Teknik Pengumpulan Data}

\section{Inventarisasi dan Keragaman Jenis Mangrove}

Inventarisasi dan penghitungan jumlah individu setiap jenis mangrove menggunakan petak contoh berbentuk garis berpetak kuadrat pada stasiun-stasiun penelitian. Sebanyak pengamatan 4 stasiun dipilih untuk dapat mewakili keseluruhan hutan mangrove Desa Daiama. Stasiun ditempatkan secara purposive pada lokasi yang memiliki keanekaragaman jenis mangrove yang dianggap paling tinggi dan penyebaran stasiun harus dapat menyebar ke seluruh lokasi hutan mangrove Desa Daiama. Pada masing-masing stasiun ditempatkan 4 plot, sehingga total plot sebanyak 16 plot transek. Ukuran plot 20 x 20 m untuk tingkat pohon (pohon berdiameter 10-20 $\mathrm{cm}$ ) dengan jarak antara plot sejauh $10 \mathrm{~m}$. Untuk pengamatan pancang (pohon berdimeter 1,5$10 \mathrm{~cm}$ ) plot berukuran $10 \times 10 \mathrm{~m}$ yang ditempatkan dalam plat pertama. Untuk pengamatan anakan (berdiameter 1,5cm dan tinggi tumbuhan 1,5 mm), plot berukuran $5 \mathrm{~m} \mathrm{x} 5 \mathrm{~m}$.

\section{Pola Pemanfaatan}

Untuk mengetahui pola pemanfaatan mangrove dilakukan dengan wawancara terhadap masyarakat Desa Daiama. Dalam penelitian ini responden terdiri dari 30 orang yang terdiri dari tokoh masyarakat, pemerintah setempat, nelayan, dan masyarakat sekitar hutan mangrove Desa Daiama.

\section{Analisis Data}

\section{Analisis struktur vegetasi mangrove}

Analisis data untuk mengetahui Indeks Nilai Penting dengan menghitung kerapatan, kerapatan relatif, frekuensi, frekuensi relatif, dominansi, dan dominansi relatif menggunakan rumus Muueller-Dombois dan Ellenberg (1974). 


$$
\begin{aligned}
& \text { Kerapatan }(\mathrm{K})=\frac{\text { jumlah individu suatu jenis }}{\text { luas seluruh wilayah pengamatan }} \\
& \text { Kerapatan Relatif }(\mathrm{KR})=\frac{\text { kerapatan spesies }}{\text { kerapatan seluruh spesies }} 100 \% \\
& \text { Frekuensi }(\mathrm{F})=\frac{\text { jumlah plot yang ditempati suatu spesies }}{\text { jumlah seluruh plot pengamatan }} \\
& \text { Frekuensi Relatif }(\mathrm{FR})=\frac{\text { frekuensi suatu spesies }}{\text { frekuensi seluruh spesies }} 100 \% \\
& \text { Dominansi }=\frac{\text { luas basal suatu spesies }}{\text { luas pengamatan }} \\
& \text { Dominansi Relatif }(\mathrm{DR})=\frac{\text { dominansi suatu spesies }}{\text { dominansi selutuh spesies }} 100 \% \\
& \text { Indek Nilai Penting(INP) untuk pohon }=\mathrm{KR}+\mathrm{FR}+\mathrm{DR} \\
& \text { Nilai Indeks Penting untuk pancang dan semai }=\mathrm{KR}+\mathrm{FR}
\end{aligned}
$$

\section{Keanekaragaman Jenis}

Keanekaragaman jenis tumbuhan mangrove ditentukan menggunakan sebuah indeks keanekaragaman, yaitu indeks Shannon-Wienner dengan rumus dan kriteria sebagai berikut (Odum,1993).

$$
\mathrm{H}^{\prime}=-\sum\left[\frac{n i}{N}\right] \log \left[\frac{n i}{n}\right]
$$

Keterangan: $H^{\prime}=$ Indeks Shannon-Wienner, ni= Indeks nilai penting jenis ke-i, $\mathrm{N}=$ Total indeks nilai penting.

Kriteria keanekaragaman jenis berdasarkan Indeks Shannon-Wienner adalah apabila H' < 1, maka keanekaragaman rendah, apabila $\mathrm{H}^{\prime}<1-3$, maka keanekaragaman sedang, dan apabila H'> 3, maka keanekaragaman tinggi (Odum, 1993).

\section{Analisis pemanfaatan}

Analisis pemanfaatan tumbuhan mangrove oleh masyarakat Desa Daiama menggunakan analisis deskriptif kualitatif.

\section{HASIL DAN PEMBAHASAN}

Keanekaragaman mangove yang ditemukan di Desa Daiama, Kecamatan Landu Leko terdiri dari 6 family, yaitu: family Rhizophoraceae, Soneratiaceae, Lythraceae, Myrsinaceae, Sapindaceae, dan Rubiaceae. Family Rhizophoraceae umumnya merupakan pohon dan perdu yang ditemukan pada kawasan tropis, family ini terdiri dari 15 genus dan sekitar 140 spesies (Schwarzbach dan Ricklefs, 2000). Family Soneratiaceae umumnya merupakan pohon dan perdu, dan hanya terdiri atas 2 genus yaitu Duabanga dan Sonneratia. Famili Lythraceae dalam ekosistem mangrove diwakili 2 genus yaitu genus Pemphis yang habitusnya perdu, sedangkan Crenea yang habitusnya sebagai tumbuhan herba (Tomlinson, 2016). Family Myrsinaceae berkisar 50 genus dengan 3 genus yang dapat ditemukan pada ekosistem mangrove yaitu Aegiceras, Ardisia dan Myrsine. Famili Rubiaceae yang dikenal sebagai penghuni ekosistem mangrove yaitu Scyphiphora dan Rustia (Rustia occidentalis). 
Ngoma et al., 2020. Keanekaragaman Mangrove dan Pemanfaatannya ...

Dari 6 family tersebut, terkonfirmasi 11 spesies mangrove yang didominasi oleh genus Rhizopora. Family Rhizophoraceae yang ditemukan di hutan Mangrove Desa Daiama terdiri atas 6 spesies yaitu Rhizophora stylosa (Bakau atau nama lokalnya Boa Maie Doloa), Rhizophora mucronata (Tanjang atau Boa Maie), Ceriops spp (Dolutu), Ceriops tagal (tengar atau tene), Ceriops decandra (tengar atau Bou kira-kira) dan Bruguiera sexangula (tanjang atau pio). Family Soneratiaceae yaitu jenis Sonneratia alba (bogem atau Boa Dosela). Family Lythraceae yaitu Pemphis acidula (sentigi atau bou), family Myrsinaceae yaitu Aegiceras floridum (gedangan atau ai massi), family Rubiaceae yaitu Scyphiphora hydrophylacea (perepat atau ninias putih), dan famili Sapindaceae yaitu Dodonaea viscosa (pawi atau peus).
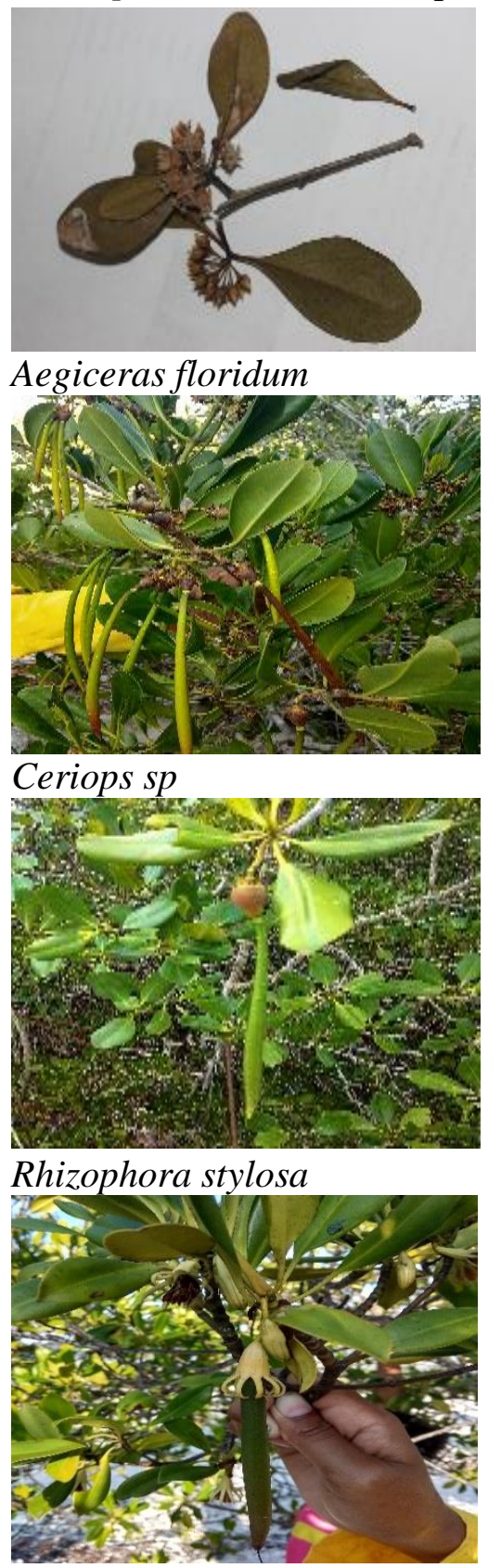

Bruguiera sexangula

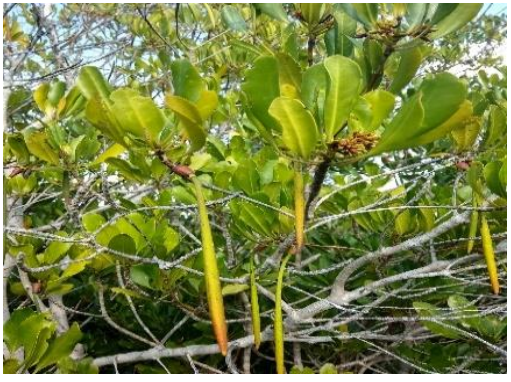

Ceriops tagal

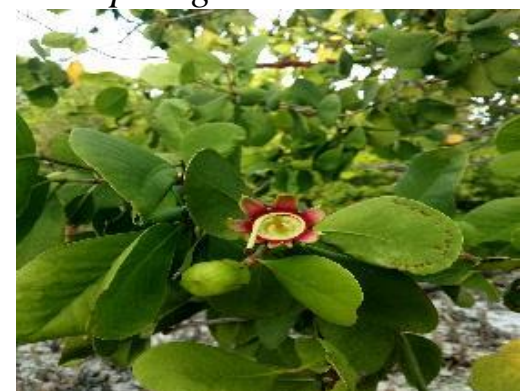

Soneratia alba

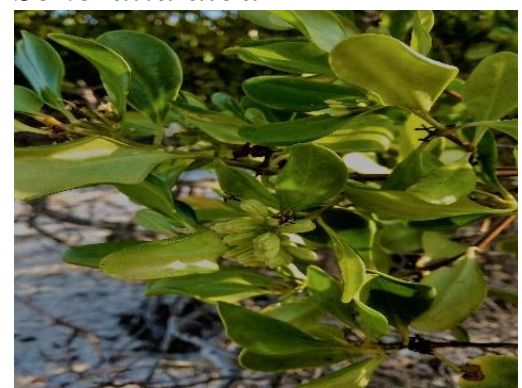

S.hydrophylacea

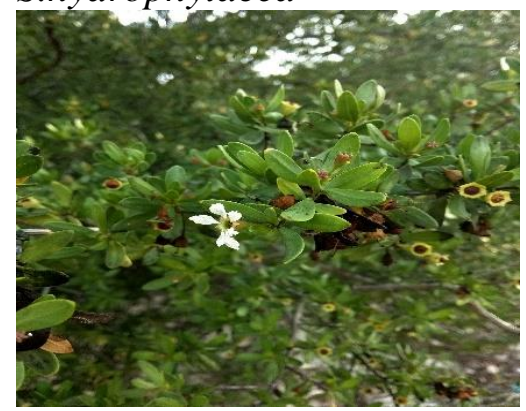

Pemphis acidula

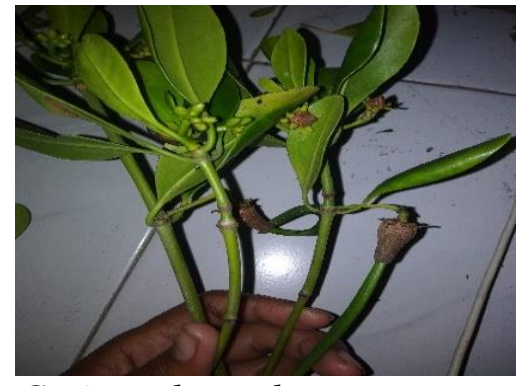

Ceriops decandra

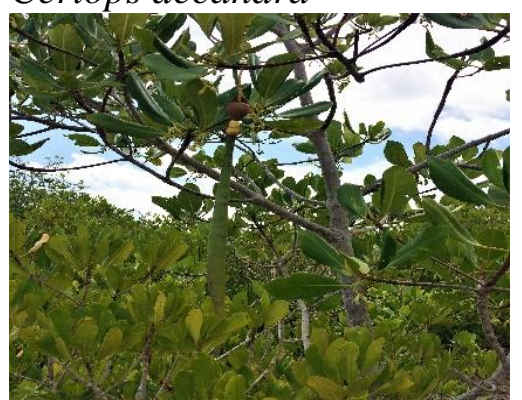

Rhizophora mucronata

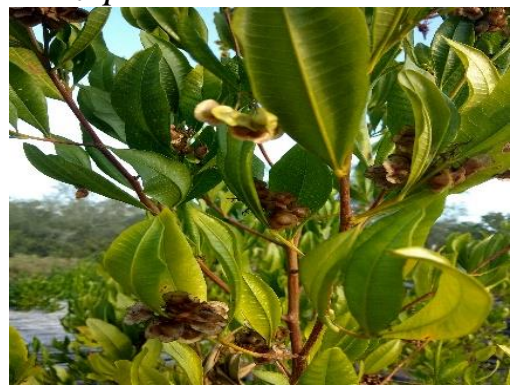

Dodonaea viscosa

Gambar 1. Jenis-jenis mangrove di Desa Daiama

Jumlah ini lebih sedikit jika dibandingkan dengan daerah lain di Nusa Tenggara Timur (NTT) seperti yang dilaporkan Bessie et al., (2013) melaporkan jumlah yang lebih banyak yaitu 
menemukan 16 jenis mangrove pada Taman Wisata Alam Laut Teluk Kupang. Hutan mangrove Desa Daiama lebih banyak dari mangrove di Hutan mangrove Pantai Paradiso yang hanya dilaporkan 2 spesies saja (Seran, 2019). Jika dibandingkan dengan daerah di luar NTT seperti di Taman Nasional Bali Barat yang dilaprokan memiliki 28 jenis mangrove (Arinasa, 2012), atau di Pulau Sepanjang, Jawa Timur yang dilaporkan memiliki 36 jenis mangrove (Rugayah et al., 2010), maka mangrove di Desa Daiama masih tergolong rendah kekayaan jenisnya. Jenis-jenis mangrove yang ditemukan di hutan mangrove Desa Daiama seperti dari genus Rhizophora, Bruguiera, Sonneratia dan umumnya sama seperti yang ditemukan di Pulau Timor (Bessie et al., 2013) dan di Pulau Menipo (Semiun et al., 2020) yang berdekatan dengan dengan Pulau Rote yang mana Desa Daiama berada. Terdapat 1 (satu) genus yang cukup dikenal yaitu Avicennia (api-api) yang tidak ditemukan di Hutan mangrove Desa Daiama, meskipun Bessie et al., (2013) melaporkan keberadaan jenis mangrove tersebut pada mangrove di Desa Tablolong yang berbatasan laut dengan Desa Daiama. Berdasarkan hasil penelusuran pada IUCN red list 2020, kesebelas jenis mangrove ini termasuk dalam kategori least concern/LC (resiko rendah) yaitu $R$. stylosa, R. mucronata, C. tagal, B. sexangula, S. alba, P. acidula, S. hydrophylacea, dan D. viscosa, sedangkan yang terkategori near threatened/NT (hampir terancam) yaitu $C$. decandra, dan A. floridum.

\section{Struktur Vegetasi Jenis Mangrove Di Desa Daiama}

Hasil analisis vegetasi mangrove di Desa Daiama ditampilkan dalam Tabel 1. di bawah ini. Berdasarkan Tabel 1. dari 11 jenis mangrove yang ditemukan di Desa Daiama yang memiliki INP tertinggi untuk tingkat pohon adalah $R$. stylosa $81,61 \%$, diikuti $R$. mucronata (INP = $77,33 \%)$, C. tagal $(\mathrm{INP}=55,6 \%)$ dan $S$. alba $(\mathrm{INP}=51,06 \%)$. Pada fase pertumbuhan pancang (Tabel 2.), INP tertinggi yaitu $C$. tagal dengan INP sebesar 40,02\%, diikuti $R$. mucronata (INP = 33,88\%), Ceriops spp (29,31\%) dan P. acidula (21, 24\%). Pada fase semai (Tabel 2.), spesies dengan INP tertinggi yaitu $P$. acidula dengan INP sebesar 59,09\%, diikuti $C$. tagal (37,22\%), D. viscosa $(29,08 \%)$ dan C. decandra $(19,08 \%)$. Berdasarkan nilai INP yang diuraikan tersebut terlihat beberapa spesies seperti $C$. tagal, dan R.mucronata dominan pada setiap fase pertumbuhan baik pohon, pancang, dan semai. Hal ini memperlihatkan spesies-spesies tersebut memiliki struktur populasi yang baik, yang memperlihatkan bahwa spesies-spesies tersebut memiliki pertumbuhan yang baik pada hutan mangrove Desa Daiama.

Tabel 1. Analisis Vegetasi Tingkat Pohon Jenis Mangrove yang Ditemukan di Desa Daiama

\begin{tabular}{lcccccccc}
\hline \multicolumn{1}{c}{ Nama spesies } & $\begin{array}{c}\text { Jumlah } \\
\text { spesies }\end{array}$ & K & KR & F & FR & D & DR & INP \\
\hline S. alba & 25 & 0,004 & 13.79 & 0,31 & 11.03 & 1,8 & 26,27 & 51,09 \\
R. mucronata & 46 & 0,007 & 24.13 & 0,88 & 31.31 & 1,5 & 21,89 & 77,33 \\
R. stylosa & 53 & 0,008 & 27.58 & 0,88 & 31.31 & 2,02 & 30,65 & 89,54 \\
C. tagal & 46 & 0,007 & 24.13 & 0,38 & 13,52 & 1,23 & 17,95 & 55,6 \\
C. decandra & 3 & 0,0004 & 1.37 & 0,06 & 2,14 & 0,05 & 0,72 & 4,23 \\
A. floridum & 3 & 0,0004 & 1.37 & 0,12 & 4.27 & 0,08 & 1,16 & 6,8 \\
Ceriops spp & 10 & 0,002 & 6.89 & 0,18 & 6.40 & 0,81 & 11,82 & 25,11 \\
\hline \multicolumn{1}{c}{ Jumlah } & 186 & 0,029 & 100 & 2,81 & 100 & 6,85 & 100 & 300 \\
\hline \multicolumn{1}{c}{} & & & & & & & &
\end{tabular}


Tabel 2. Analisis Vegetasi Tingat Pancang dan Semai Jenis Mangrove di Desa Daiama

\begin{tabular}{lccrrrc}
\hline \multicolumn{1}{c}{ Nama spesies } & $\begin{array}{c}\text { Jumlah } \\
\text { Spesies }\end{array}$ & K & KR & F & FR & INP \\
\hline S. alba & 9 & 0,006 & 4,51 & 0,25 & 5,35 & 9,86 \\
R. mucronata & 36 & 0,022 & 16,54 & 0,81 & 17,34 & 33,88 \\
R. stylosa & 19 & 0,011 & 8,27 & 0,44 & 9,42 & 17,69 \\
C. tagal & 63 & 0,039 & 29,32 & 0,5 & 10,70 & 40,02 \\
C. decandra & 5 & 0,003 & 2,25 & 0,12 & 2,56 & 4,81 \\
P. acidula & 23 & 0,014 & 10,53 & 0,5 & 10,71 & 21,24 \\
D. viscosa & 17 & 0,010 & 7,52 & 0,38 & 8,14 & 15,66 \\
B. sexangula & 9 & 0,006 & 4,51 & 0,25 & 5,35 & 9,86 \\
Ceriops spp & 32 & 0,02 & 15,04 & 0,62 & 14,27 & 29,31 \\
S. hydrophyllaceae & 4 & 0,002 & 1,50 & 0,8 & 17,13 & 18,63 \\
\hline Jumlah (Pancang) & $\mathbf{2 1 7}$ & $\mathbf{0 , 1 3 3}$ & $\mathbf{1 0 0}$ & $\mathbf{4 , 6 7}$ & $\mathbf{1 0 0}$ & $\mathbf{2 0 0}$ \\
\hline S. alba & 11 & 0,027 & 4,47 & 0,125 & 3,99 & 8,46 \\
R. stylosa & 9 & 0,022 & 3,64 & 0,187 & 5,96 & 9,61 \\
R. mucronata & 5 & 0,012 & 1,99 & 0,125 & 3,99 & 5,98 \\
C. tagal & 32 & 0,08 & 13,26 & 0,75 & 23,96 & 37,22 \\
D. viscosa & 22 & 0,055 & 9,12 & 0,625 & 19,96 & 29,08 \\
S.hydrophyllaceae & 2 & 0,005 & 0,83 & 0,062 & 1,98 & 2,81 \\
P. acidula & 104 & 0,26 & 43,12 & 0,5 & 15,97 & 59,09 \\
Ceriops spp & 9 & 0,033 & 3,64 & 0,187 & 5,97 & 9,61 \\
C.decandra & 22 & 0,055 & 9,12 & 0,312 & 9,96 & 19,08 \\
B. sexangula & 26 & 0,065 & 10,77 & 0,25 & 7,69 & 18,46 \\
\hline \multicolumn{1}{c}{ Jumlah (Semai) } & $\mathbf{2 4 2}$ & $\mathbf{0 , 6 0 3}$ & $\mathbf{9 9 , 9 6}$ & $\mathbf{3 , 1 3}$ & $\mathbf{1 0 0}$ & $\mathbf{1 9 9 , 8}$ \\
\hline
\end{tabular}

\section{Indeks Keanekaragaman Jenis}

Pada stasiun 1 memiliki indeks keanekaragaman 2,00 stasiun 2 memiliki indeks keanekaragaman 1,79 stasiun 3 memiliki indeks keanekaragaman 1,96 dan stasiun 4 memiliki indeks keanekaragaman 1,67. Berdasarkan kriteria indeks keanekaragaman Shannon-Wiener jika $\mathrm{H}^{1}>3$, menunjukkan keanekaragaman jenis tinggi, jika $\mathrm{H}^{1} 1 \leq \mathrm{H}^{1} \leq 3$ keanekaragaman spesies sedang, dan jika $\mathrm{H}^{1}<1$ keanekaragaman spesies sedikit atau rendah. Berdasarkan hal di atas maka dapat disimpulkan bahwa keanekaragaman mangrove pada setiap stasiun di Desa Daiama, memiliki keanekaragaman terkategori sedang pada setiap stasiun pengamatan. Menurut Indriyanto (2008), suatu komunitas dikatakan memiliki keanekaragaman spesies yang tinggi jika komunitas itu disusun oleh banyak spesies. Sebaliknya suatu komunitas dikatakan memiliki keanekaragaman spesies yang rendah jika komunitas itu disusun oleh sedikit spesies dan jika hanya ada sedikit saja spesies yang dominan. Karena itu jika dilihat dari nilai keanekaragaman yang tergolong sedang tersebut maka diketahui mangrove di desa Daiama masih memiliki mangrove dengan jenis yang beragam dan jumlah populasi setiap spesiesnya tidak ada yang sangat dominan. Hal ini dapat disebabkan oleh kondisi ekosistem mangrove yang mampu mendukung kehidupan setiap jenis mangrove.

Dari setiap jenis mangrove yang ditemukan di Desa Daiama memiliki kebutuhan kondisi lingkungan terutama substrat yang bervariasi. Seperti $R$. mucronata menyukai habitat yang mengalami genangan air, $R$. stylosa daerah berlumpur, berpasir dan bisa pula pada daerah berkarang (Kartika et al., 2018). C. tagal umumnya pada daerah lumpur pejal, S. alba pada daerah berlumpur dan karang. P. acidula dan A. floridum pada daerah pasir dan karang (Arinasa, 
2012). Daerah mangrove di Desa Daiama mempunyai substrat beraneka ragam dari daerah lumpur yang mengalami genangan, daerah berpasir dan berkarang maupun daerah berpasir yang lebih kering. Karena substrat yang beragam ini mampu mendukung keanekaragaman mangrove yang tergolong sedang di Desa Daiama. Keanekaragaman mangrove di Desa Daiama berdasarkan nilai indeks Shannon-Wiener sama seperti yang dilaporkan Kartika et al., (2018) pada mangrove UPT KPHP Bulungan unit VIII Kalimantan Utara dan Bessie dkk (2013) pada mangrove TWAL Teluk Kupang yang nilai keanekaragamannya rendah sampai sedang. Menurut Kusmana (1996) dan Giesen et al., (2006) keanakeragaman jenis dan kekayaan spesies yang rendah pada ekosistem mangrove dikarenakan tidak banyak spesies yang mampu bertahan hidup pada ekosistem tersebut. Hal ini karena kondisi lingkungan ekosistem mangrove yang selalu mengalami genangan air dan juga memiliki salinitas yang tinggi.

\section{Pemanfatan Jenis Mangvore di Desa Daiama}

Jenis-jenis tumbuhan mangrove yang paling banyak pemanfaatannya di Desa Daiama yaitu sebagai bahan kontruksi untuk tiang bangunan rumah dan bahan pembuatan perahu. Jenis-jenis yang dimanfaatkan untuk tujuan tersebut adalah Sonneratia alba, Rhizophora mucronata, dan Rhizophora stylosa. Setyawan dan Winarno (2006) juga menyatakan bahwa jenis mangrove dari genus Rhizophora dan Sonneratia dimanfaatkan sebagai bahan konstruksi. Jenis mangrove lain yang dilaporkan juga dimanfaatkan sebagai bahan konstruksi yaitu Bruguiera, Pandanus, dan jenis Ceriops decandra (Dekme et al., 2016; Kartika et al., 2018). Jenis-jenis tersebut juga ditemukan di Hutan Mangrove Desa Daiama namun tidak dimanfaatkan sebagai bahan konstruksi. Sonneratia alba, Rhizophora mucronata, dan Rhizophora stylosa juga dimanfaatkan sebagai bahan makanan dan pembuatan kue oleh masyarakat Desa Daiama. Ini juga sesuai yang dinyatakan oleh Setyawan dan Winarno (2006) Avicennia sp dijadikan sayur, buah Sonneratia spp., dan propagul Rhizophora spp dikonsumsi oleh masyarakat di Jawa Tengah.

Tabel 3. Pemanfaatan Mangrove di Desa Daiama

\begin{tabular}{|c|c|c|c|c|c|}
\hline No & Nama latin & $\begin{array}{c}\text { Nama } \\
\text { Indonesia }\end{array}$ & $\begin{array}{c}\text { Nama } \\
\text { lokal }\end{array}$ & Pemanfatan & $\begin{array}{c}\text { Bagian yang } \\
\text { dimanfaatkan }\end{array}$ \\
\hline 1 & A. floridum & Gedangan & Ai massi & - & - \\
\hline 2 & Ceriops tagal & Tengar & Tene & $\begin{array}{l}\text { Pewarna alami } \\
\text { tenunan }\end{array}$ & Kulit \\
\hline 3 & Ceriops decandra & Tengal & Bou kira-kira & Pengganti pinang & Buah \\
\hline 4 & Ceriops spp & Tengar & Dolutu & - & - \\
\hline 5 & Sonneratia alba & Bogem & Boa dosela & $\begin{array}{l}\text { Bahan makanan dan } \\
\text { kue, papan perahu dan } \\
\text { tiang rumah }\end{array}$ & Buah dan kayu \\
\hline 6 & R. mucronata & $\begin{array}{l}\text { Tanjang / } \\
\text { Lanang }\end{array}$ & Boa maie & $\begin{array}{l}\text { Bahan makanan, tiang } \\
\text { rumah dan papan } \\
\text { perahu }\end{array}$ & $\begin{array}{l}\text { Buah, kelopak } \\
\text { dan kayu }\end{array}$ \\
\hline 7 & R.stylosa & Bakau & $\begin{array}{l}\text { Boa maie } \\
\text { doloa }\end{array}$ & $\begin{array}{l}\text { Bahan makanan, tiang } \\
\text { rumah }\end{array}$ & Buah dan kayu \\
\hline 8 & S. hydrophyllcea & Perepat & Ninias putih & - & - \\
\hline 9 & D.viscosa & Pawi & Peus & - & - \\
\hline 10 & B.sexangula & Tanjang & Pio & Bahan obatan & Daun \\
\hline 11 & Pemphis acidula & Sentigi & Bou & $\begin{array}{l}\text { Pohon hias dan kulit } \\
\text { dijadikan obat }\end{array}$ & $\begin{array}{l}\text { Batang, daun, } \\
\text { dan bunga }\end{array}$ \\
\hline
\end{tabular}


Pemanfaatan lain jenis mangrove yaitu sebagai pewarna alami tenunan. Jenis mangrove yang dimanfaatkan untuk tujuan ini yaitu Ceriops tagal, pewarna dihasilkan dari kulit kayu tanaman ini. Rugayah et al., (2010) juga menyatakan hal yang sama bahwa bagian kulit Ceriops tagal dimanfaatkan masyarakat Pulau Sepanjang Jawa Timur sebagai pewarna batik. Pemanfaatan jenis mangrove lain yaitu Pemphis acidula sebagai tanaman hias dan bahan obat. $P$. acidula atau sentigi telah diketahui merupakan salah buruan untuk dijadikan tanaman hias (bonsai) maupun tongkat sentigi (Rugayah et al., 2010; Arinasa, 2012). Penggunaan $P$. acidula sebagai bahan obat ditegaskan oleh Hardjito (2007) bahwa kulit batang P. acidula mampu menghambat aktivitas bakteri dan juga mengandung antioksidan. Jenis mangrove yang juga digunakan sebagai bahan obat oleh masyarakat Desa Daiama yaitu Bruguiera sexangula, sedangkan Ceriops decandra digunakan masyarakat Desa Daiama sebagai pengganti pinang untuk dimakan. Terdapat 4 jenis mangrove yang tidak diketahui pemanfaatannya oleh masyarakat Desa Daiama yaitu A. floridum, Ceriops spp, S. Hydrophyllcea dan D. viscosa.

\section{KESIMPULAN}

Jenis mangrove yang ditemukan pada lokasi penelitian terdiri dari 11 jenis antara lain: Rhizophora stylosa, Rhizophora mucronata, Ceriops spp, Ceriops tagal, Ceriops decandra, Bruguiera sexangula, Soneratia alba, Pemphis acidula, Aegiceras floridum, S.hydrophylacea, dan Dodonaea viscosa. Dari 11 jenis mangrove yang memiliki INP tertinggi untuk tingkat pohon adalah $R$. stylosa 81,61\%, untuk tingkat pancang adalah Ceriops spp dengan INP 44,85\%, dan untuk tingkat semai adalah Pemphis acidula dengan INP 59,09\%. Indeks keanekaragaman mangrove di Desa Daiama tergolong sedang pada setiap stasiun (indeks keanekaragaman berkisar 1,67-2,00). Pemanfaatan mangrove di Desa Daiama digunakan sebagai bahan obat, kayunya dijadikan bahan bangunan dan pembuatan perahu, sebagian dari buah mangrove bisa dijadikan bahan makanan, digunakan sebagai pohon hias, dan ada juga yang digunakan sebagai pewarna alami kain tenun.

\section{REFERENSI}

Alwidakdo, A., Azham, Z., and Kamarubayana, L. 2014. Studi Pertumbuhan Mangrove Pada Kegiatan Rehabilitasi Hutan Mangrove Di Desa Tanjung Limau Kecamatan Muara Badak Kabupaten Kutai Kartanegara. Jurnal AGRIFOR, 13(1): 11-18.

Arinasa, I.B.K. 2012. Keanekaragaman Tumbuhan Mangrove Di Taman Nasional Bali Barat. Buletin Kebun Raya, 15 (1): 10-20.

Bessie, D.M., Schaduw, J.N., Reppie, E., dan Lasut, M.T. 2013. Community structure of mangrove at Marine Tourism Park of Kupang Bay, East Nusa Tenggara. Aquatic Science \& Management, Edisi Khusus, (1): 3-9. https://doi.org/10.35800/jasm.0.0.2013.2270

Dahuri, RJ., Rais, SP., Ginting, dan Sitepu, M.J. 1996. Pengelolaan Sumberdaya Wilayah Pesisir dan Lautan Secara Terpadu. PT. Pradnya Paramita, Jakarta. 326 hlm.

Davinsy, R., Kustanti, A., and Hilmanto, R. 2015. Study of mangrove forest management in the Pahawang Island Village Marga Punduh District Pesawaran Regency. Sylva Lestari, 3(3): 95-106.

Dekme, Z.F., Lasut, M.T., Thomas, A., dan Kainde, R.P. 2016. Keanekaragaman Jenis Tumbuhan Di Hutan Mangrove Kecamatan Tombariri Kabupaten Minahasa. Cocos, 7(2): 1-7. 
Dencer-Brown, A.M., Alfaro, A.C., Milne, S., and Perrot, J. 2018. A Review on Biodiversity, Ecosystem Services, and Perceptions of New Zealand's Mangroves: Can We Make Informed Decisions about Their Removal?. Resources, 7(23): 1-21. doi:10.3390/resources7010023

Febryano, I. G., Suharjito, D., Darusman, D., Kusmana, C., and Hidayat, A. 2014. The Roles and Sustainability of Local Institutions of Mangrove Management in Pahawang Island. Jurnal Manajemen Hutan Tropika, 20(2): 69-76.

Giesen, W., Wulfraat S., Zieren, M., and Scholten, L. 2006. Mangrove Guide Book for Southeast Asia. Bangkok (TH): FAO and Wetlands International, Dharmasarn Co.Ltd. pp 769.

Hardjito, L. 2007. Antibacterial, Antioxidant and Topoisomerase-I Inhibitor Activities Of The Coastal Ethnomedicinal Plant Pemphis acidula. Biotropia 14(2): 43-51.

Indriyanto. 2008. Ekologi Hutan. PT. Bumi Aksara. Jakarta. Cetakan ke-2. 210 hlm.

Jumaedi, S. 2016. Nilai Manfaat Hutan Mangrove dan Faktor-Faktor Penyebab Konversi Zona Sabuk Hijau (Greenbelt) Menjadi Tambak di Wilayah Pesisir Kota Singkawang Kalimantan Barat. Sosiohumaniora, 18(3): 227-234.

Kai, M., Genyou, L., Leijie, Z., Caixia, Y., and Houhua, X. 2013. Population structure and distribution patterns of the rare and endangered Ardisia violacea (Myrsinaceae). Acta Ecologica Sinica, 33: 72-79.

Kartika, K.F., Istomo, dan Amanah, S. 2018. Keanekaragaman Jenis Mangrove Di Upt Kphp Bulungan Unit VIII Kalimantan Utara. Media Konservasi, 23(3): 253-261.

Kusmana, C. 1996. Nilai ekologis ekosistem hutan mangrove. Media Konservasi. 5(1): 17-24.

Kusmana, C., Istomo, Wibowo, C., Budi, S.W., Siregar, I.Z., Riyana, T., dan Sukardjo, S. 2002. Manual Silvikultur Mangrove di Indonesia. Departemen Kehutanan Republik Indonesia dan Korea International Cooperation Agency (KOICA). Jakarta. 226 hlm.

Li, W., and Zhang G.F. 2015. Population structure and spatial pattern of the endemic and endangered subtropical tree Parrotia subaequalis (Hamamelidaceae). Flora, 212: 10-18.

Mueller-Dombois, D., and Ellenberg, H. 1974. Aims and Methods of Vegetation Ecology. John Wiley and Sons. New York. 574 pp

Muryani, C., Ahmad, Nugraha, S., dan Utami, T., 2011. Model Pemberdayaan Masyarakat dalam Pengelolaan dan Pelestarian Hutan Mangrove di Pantai Pasuruan Jawa Timur. Jurnal Manusia dan Lingkungan, 18(2): 75-84.

Odum, E.P. 1993. Dasar-dasar Ekologi. Terjemahan oleh Tjahjono Samingan dari buku Fundamentals of Ecology. Gadjah Mada University Press. Yogyakarta. 697 hlm.

Poedjirahajoe, E., and Matatula. 2019. The Physiochemical Condition of Mangrove Ecosystems in The Coastal District of Sulamo, Kupang, East Nusa Tenggara, Indonesia. Jurnal Manajemen Hutan Tropika, 25(3): 173-184. DOI: 10.7226/jtfm 5.3.173

Ramses, Notowinarto, dan Dewi, I.S. 2014. Struktur Komunitas Mollusca Penempel Pada Vegetasi Mangrove Di Pulau Kasu Kecamatan Belakang Padang Kota Batam. Simbiosa, 3(1): 11-17.

Ramses. 2016. Inventarisasi Karagaman Jenis Flora Mangrove di Pulau Mecan Kota Batam. Simbiosa, 5(2): 126-134. 
Ngoma et al., 2020. Keanekaragaman Mangrove dan Pemanfaatannya ...

Rugayah, Suhardjono, dan Susiarti, S. 2010. Keanekaragaman Tumbuhan Pulau Sepanjang Jawa Timur. Berita Biologi, 10(2): 205-214. 10.14203/beritabiologi.v10i2.1974

Schwarzbach, A.E., and Ricklefs, R.E. 2000. Systematic Affinities Of Rhizophoraceae And Anisophylleaceae, And Intergeneric Relationships Within Rhizophoraceae, Based On Chloroplast DNA, Nuclear Ribosomal DNA, and Morphology. American Journal of Botany, 87(4): 547-564.

Semiun, C.G., Lengur, E.R.A., and Duhan, G.U.U.B. 2020. Insect diversity profile of mangrove ecosystem in Menipo Nature Tourism Park, East Amarasi, East Nusa Tenggara. IOP Conf. Series: Materials Science and Engineering, 823: 1-9. International Seminar on Chemical Engineering Soehadi Reksowardojo (STKSR) 2019. 7-9 October 2019, Kupang, Indonesia. doi:10.1088/1757-899X/823/1/012050

Seran, W. 2019. Struktur dan Komposisi Spesies Hutan Mangrove di Pantai Paradiso, Kota Kupang, NTT. Jurnal Agribisnis dan Perikanan, 12(1): 34-42. doi: 10.29239/j.agrikan.11.1.43-41

Setyawan, A.D. dan Winarno, K. 2006. Pemanfaatan Langsung Ekosistem Mangrove di Jawa Tengah dan Penggunaan Lahan di Sekitarnya; Kerusakan dan Upaya Restorasinya. Biodiversitas, 7(3): 282-291. doi :10.13057/Biodiv/d070318

Thomas, N., Lucas, R., Bunting, P., Hardy, A., Rosenqvist, A., and Simard, M. 2017. Distribution and drivers of global mangrove forest change, 1996 \pm 2010 . PLOS ONE, 12(6): e0179302. https://doi.org/10.1371/journal.pone.0179302

Timuli, Y.A. 2015. Inventarisasi dan Keanekaragaman Jenis Mangrove di Pantai Kaisulun, Desa Akle Kecematan Semau Kabupaten Kupang. (Skripsi). Universitas Kristen Artha Wacana. Kupang.

Tomlinson, P.B. 2016. Family: Lythraceae. In The Botany of Mangroves. Cambridge University Press. Cambridge. pp. 268-271. doi:10.1017/CBO9781139946575.031

Utomo, B., Budiastuti, S dan Muryani, C. 2017. Strategi Pengelolaan Hutan Mangrove Di Desa Tanggul Tlare, Kecamatan Kedung, Kabupaten Jepara. Jurnal Ilmu Lingkungan, 15(2): 117-123. doi:10.14710/jil.15.2.117-123

\section{Authors:}

Ratna B. Ngoma, Universitas Kristen Artha Wacana, J1 adi sutjipto, Oesapa, Kodepos 85228, Propinsi Nusa Tenggara Timur, Negara Indonesia, email: ratnangoma@gmail.com

Arnold Ch Hendrik, Universitas Kristen Artha Wacana, Jl adi sutjipto, Oesapa, Kodepos 85228, Propinsi Nusa Tenggara Timur, Negara Indonesia, email: Arnold_hendrik@yahoo.co.id

Apriliana Ballo, Universitas Kristen Artha Wacana, J1 adi sutjipto, Oesapa, Kodepos 85228, Propinsi Nusa Tenggara Timur, Negara Indonesia email: apriballo@gmail.com

This is an open-access article distributed under the terms of the Creative Commons Attribution License, which permits unrestricted use, distribution and reproduction in any medium, provided the original author and source are credited. (http://creativecommons.org/licenses/by/4.0/).

How to cite this article:

Ngoma, R.B., Hendrik, A.C., and Ballo, A. 2020. Mangrove diversity and its use in Daiama village, Landu Leko District, Rote Ndao Regency, East Nusa Tenggara Province. Simbiosa, 9(2): 118-128. Doi. http://dx.doi.org/10.33373/sim-bio.v9i2.2498 